correlate their results with those obtained in other regions by the application of methods which alone can make a botanical survey what it is now generally expected to be-a correlated study of the plant communities and the plant habitats of the area surveyed.

F. C.

\section{ORNITHOLOGICAL NOTES.}

$A \mathrm{~T}$ the annual meeting of the Royal Society for the A Protection of Birds, held at the Middlesex Guildhall, on March Ix, when the Ranee of Sarawak presided, an optimistic tone prevailed in the first portion of the report for 19I4, as several of the schemes and objects. for which the Society had long been labouring were apparently on the point of realisation. Then came the war, when all these fair prospectsparticularly the expected passing of the Government Plumage Bill-were dissipated, to be renewed, it may be hoped, at the conclusion of the war. In other respects the work of the Society was, on the whole, satisfactory; but finance is a matter on which there is serious ground for anxiety, as a falling-off in subscriptions during the current year is almost inevitable.

The condor forms the subject of the first article in the March number of the Children's Museum News, where particular reference is made to the long period taken by these birds to attain the adult plumage. Hatched during the height of the southern summer, the young exchange their white nestling dress for a uniformly brown garb, which is not finally discarded until the seventh year, in February or the early part of March. Although able to fly when a year old, young condors do not leave their parents until the completion of their third year.

In the course of a wonderfully illustrated article on a breeding-colony of buff-backed herons, published in the March issue of Wild Life, Mr. B. Beetham directs attention to the small size of the nests of these birds, which alone renders it possible for so many to be crowded into a single bush. So heavily weighted, indeed, are some of the boughs that they hang almost vertically; and it is little short of marvellous how the eggs and young are retained in the shallow, cup-like nests, generally overhanging a lagoon, into which the hapless offspring may be precipitated by a gust of greater strength than usual. The nests are devoid of lining, and in some cases so flimsy in structure that the pale blue eggs are visible from below.

The nesting-habits of fulmar-petrels on a precipitous cliff in the Orkneys form the subject of an article by Mr. O. G. Pike in British Birds for March. The author arrived on the scene in the second week in July, when most of the young were hatched; but he was able to secure a couple of photographs of sitting birds, as well as one of a downy nestling. Each female lays but a single egg, and at a very early stage the young bird is capable of indulging in the distinctly petrel-trait of discharging a forceful jet of evil-smelling green oil from its mouth in the face of a real or supposed enemy.

To the Journal of the Straits Branch of the Royal Asiatic Society for December, I9r4, Mr. I. C. Moulton, curator of the Sarawak Museum, contributes a list of Bornean birds. In an appendix to Hugh Low's "Sarawak," published in 1848 , the number of species then recognised was fifty-nine; this was raised in I889 in a list drawn up by the late Mr. A. H. Everett to 536 (exclusive of thirty-four from Palawan), while in the present list the number is again augmented to 555; and this, too, despite the fact that several birds formerly regarded as distinct species have been relegated to the rank of local races.

NO. 2372 , VOL. 95]
According to the report in the January number of the Emu, the fourteenth annual session of the Royal Australasian Ornithologists" Union, held in Melbourne in November, I9I4, was a thorough success, a number of interesting excursions being taken and several papers read. In the same issue $\mathrm{Mr}$. A. J. Campbell directs attention to the apparent extermination of three beautifully coloured species of parrotsnamely, the scarlet-shouldered Psephotus pulcherrimus, the chestnut-shouldered grass-parrot (Euphema pulchella), and the night-parrot (Geopsittacus occidentalis), all of which were to be met with a few years ago in Queensland or the neighbouring districts. Their disappearance is attributed to domesticated cats run wild, aided by bush-fires and the spread of cultivation.

In the Zoologist for March, Prof. J. C. Patten describes an immature aquatic warbler picked up at Tuskar light-station, County Wexford, on August 9, I9I3. The paper is illustrated by a plate showing how the plumage of this species differs from that of the sedge-warbler at the same age. In the aquatic warbler the back is marked by streaks of black and buff, which are but slightly developed in the sedgewarbler; both webs of the middle pair of tail-feathers are also margined with buff, and all the tail-feathers are likewise longer, narrower, and more pointed than those of the sedge-warbler. The Tuskar bird is the second of its kind taken in Ireland; the number of specimens recorded from Great Britain (England) is seventeen.

R. L.

MOUNTAIN GEOLOGY.

$\mathrm{I}$ the Mémoires de la Société de Physique et d'His1 toire Naturelle de Genève (vol. xxxviii., pages 69-168). M. Louis Duparc and Mme. M. Tikanowitch continue their work on the Ural Chain by an account of its rocks to the east of the main watershed and in the upper basin of the rivers Kakwa and Wagran. This, the fourth of their contributions to the geology of that chain, is prefaced by a sketch of the physical features of the district, the illustrations to which show that it consists of huge hills rather than of rugged mountains. The rocks are partly sedimentary, arenaceous, or slaty argillaceous, with some quartzose crystalline schists; partly igneous. Of the latter a very complete petrographical study has been made, including chemical analyses of the principal types, several of which are very interesting. Among those of deep-seated origin are the following: quartz-bearing micaceous diorites (evidently allied to tonalites) and gabbrodiorites (in which probably the hornblende is secondary), olivine-gabbros, and massive dunites. Besides these and serpentines, are tilaite (a variety of eucrite) and pyroxenites. This association is interesting, for it often exists, more or less completely, in other regions, and suggests certain modes of magmatic differentiation. The dyke-rocks include hornblendic berbachites and various dioritic porphyrites, besides amphibolites, in some at least of which the hornblende appears to be secondary. The article ends with a description of the crystalline schists which, however, do not appear to be of any unusual interest. The memoir, illustrated by twelve photographic figures of the microscopic structure of the more interesting rocks, forms a most welcome addition to petrology, the more remarkable when we learn the difficulties with which the authors had to contend in their three visits to this region, in consequence of the sparse population, the want of roads, and the absence of maps.

In the next fascicule (pp. I69-98) M. Jules Favre describes the relation of the plant-life to the geology 
of the Salève. This mountain, which rises about $3000 \mathrm{ft}$. above Geneva, consists of limestones and shales (Upper Jurassic and Neocomian), with Middle Tertiary sandstones, chiefly molasse, and glacial deposits. Apart from the effects of altitude, the flora is much affected bv the nature of the rock on which it grows, and besides this, a small colony of special plants generally accompanies any local physical pecularity. Of this association the large erratics of Alpine granite and schists afford a remarkable instance. Asplenium septentrionale is the only phanerogamous plant found on them to which rocks, in the High Alps, it is practically restricted.

\section{BLOOD-PARASITES AND FLEAS.}

G OR the past five years Prof. E. A. Minchin and Dr. J. D. Thomson have been engaged upon the investigation of the rat trypanosome, Trypanosoma lewisi, with special reference to its relation to the rat fiea, Ceratophyllus fasciatus. The results of this laborious and painstaking research are now published in the Quarterly Journal of Microscopical Science. They form a comprehensive monograph which occupies the whole of the last part of this journal (vol. 1x., part 4) and will undoubtedly be a standard work of reference for students of these very important bloodparasites. The fact that the authors have dissected and examined more than 1600 fleas in the course of their investigations shows the thoroughness with which the work has bien carried out, while the artistic treatment and accuracy of detail contributed by the illustrations, for which due acknowledgment is made to Miss Rhodes, leave nothing to be desired. $T$. lewisi is fortunately a non-pathogenic parasite, at any rate so far as the rat is concerned, and it cannot live at all in human blood. It therefore forms a much more suitable type for general study than such deadly species as those which are conveyed by the tsetse-fly in Africa, and are responsible for fly-disease amongst horses and cattle, and for sleeping sickness in human beings. The authors give a very useful account of the technique employed in their investigations, and, incidentally, throw a good deal of light upon details of the anatomy and histology of the flea.

The flea, of course, receives the parasite with the blood which it extracts from the rat, but apparently it cannot infect the rat by inoculating trypanosomes into it through the proboscis. The rat is supposed to become infected through the mouth; in the process of licking its fur it takes in trypanosomes with fæcal matter deposited by the flea; or it may become infected by eating infected fleas.

While in the flea the trypanosome is confined throughout its whole development to the digestive tract, where it undergoes extensive asexual multiplication and passes through a number of more or less distinct phases, some of which are intracellular in the epithelium of the stomach. No sexual phenomena have been detected, and the authors agree with Miss Robertson that such phenomena have not as yet been satisfactorily demonstrated in the case of any trypanosome.

\section{CHANGES OF RELATIVE LEVELS OF LAND AND SEA.}

$A$ MONG the different kinds of evidence showing that changes in the relative levels of sea and land are going on all over the globe, the forms assumed by coast-lines are now recognised by geologists as being the most convincing and satisfactory. Sea-erosion, acting only along shore-lines, and subaerial denudation, operating over the whole landNO. 2372 , VOL. 95] surfaces, result in features of such clearly differentiated character that no unbiassed observer can fail to recognise their great significance and value. When we find long, narrow, deep, and winding inlets from the sea into the land ("fiords," etc.), it is obvious that such features could not result from the cutting back of the coast-line by the sea, but that they are old river-channels that have been drowned by the sinking of the land. On the other hand, sea-beaches, with caves, fan-taluses, and other signs of shore work, occurring at various heights above the present sea-level, speak, quite as unmistakably, of elevation having taken place.

The illustrious American geologist, James Dwight Dana, when accompanying the United States Exploring Expedition under Wilkes, had the opportunity of visiting many coral-reef islands, and we are indebted to him for first showing, in 1849 , the value of the evidence afforded by coast-lines, where bounded by "encircling" or "barrier" reefs, of subsidence having taken place. These valuable observations of Dana seem to have been almost completely overlooked until quite recent years, and it is only fitting that to a fellow-countryman of his should fall the task of recalling and developing this pioneer work.

Where a coral-reef encircles a land-mass it is evident that the presence of "fiords" or their equivalents in the central island supplies clear evidence of submergence having taken place, though possibly this may not be the latest of the movements that have occurred. On the other hand, the existence of islands composed of upraised coral-rock, with sea-caves and shore deposits at different stages, up to more than $1000 \mathrm{ft}$. above the present sea-level, supplies equally clear evidence of movements in an opposite direction having taken place. The late Prof. Alexander Agassiz published a very valuable series of reports, abundantly illustrated, concerning these upraised Pacific reefs, and we now have the promise of equally important descriptions by Prof. W. M. Davis, also of Harvard, of the cases in which the proofs of subsidences can be no less satisfactorily made out.

The general result to which these various observations appear to point is that, over the whole area of the Pacific, areas of elevation and others of subsidence can be clearly traced, though the movements were often interrupted and sometimes reversed; nevertheless, it must be admitted that in some cases the evidence seems puzzling and contradictory-islands with clear evidence of elevation lying in close proximity to others which have clearly subsided. Geologists will not, however, be unprepared for the occurrence of such seeming anomalies; they will only recognise that, eventually, actual fault-lines may be traced by such means in the oceanic areas. At the same time it may be well to bear in mind the caution suggested by Darwin in his correspondence with Semper that, however clear may be the evidence in favour of any special theory of coral-reef formation, we must be always prepared for the occurrence of special cases which can only be accounted for by the operation of exceptional causes. The full and complete accountwhich will no doubt be sufficiently illustrated-of Prof. W. M. Davis's important series of explorations will be looked forward to with special interest, and in the meantime the subjoined general summary of his results will be welcomed by all naturalists.

J. W. J.

\section{Preliminary Report on a Shaler Memorial Study of} Coral Reefs.

A liberal grant from the Shaler Memorial Fund of Harvard University, supplemented by a generous subsidy from the British Association for the Advance- 